A Social Ontology 
This page intentionally left blank 


\section{A Social Ontology}

David Weissman

Yale University Press

New Haven and London 
Chapter Six, "Free Speech," was adapted from an article that appeared in Metaphilosophy, volume 27, no. 4, October, 1996.

Copyright $(0) 2000$ by Yale University.

All rights reserved.

This book may not be reproduced, in whole or in part, including illustrations, in any form (beyond that copying permitted by Sections 107 and 108 of the U.S. Copyright Law and except by reviewers for the public press), without written permission from the publishers.

Set in Adobe Garamond with Stone Sans display type

by The Composing Room of Michigan, Inc.

Printed in the United States of America.

Library of Congress Cataloging-in-Publication Data

Weissman, David, 1936-

A social ontology / David Weissman.

p. $\mathrm{cm}$.

Includes bibliographical references.

ISBN 0-300-07903-6 (alk. paper)

I. Social systems. 2. Ontology. I. Title.

HM70r.W45 2000

$301-\mathrm{dc} 2 \mathrm{r}$

99-26249

CIP

A catalogue record for this book is available from the British Library.

The paper in this book meets the guidelines for permanence and durability of the Committee on Production Guidelines for Book Longevity of the Council on Library Resources.

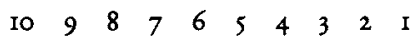


In memory of Justus Buchler 
This page intentionally left blank 